\title{
Inter-relationships among gonadotrophins, reproductive steroids and inhibin in freemartin ewes
}

\author{
T. J. Parkinson ${ }^{1}$, K. C. Smith², S. E. Long², J. A. Douthwaite², \\ G. E. Mann ${ }^{3}$ and P. G. Knight ${ }^{4}$ \\ ${ }^{1}$ Institute of Veterinary, Animal and Biomedical Sciences, Massey University, Private Bag \\ 11-222, Palmerston North, New Zealand; ${ }^{2}$ Department of Clinical Veterinary Science, \\ University of Bristol, Langford House, Langford, Bristol BS4O 7DU, UK; ${ }^{3}$ Faculty of \\ Agricultural and Food Sciences, University of Nottingham, Sutton Bonington, \\ Loughborough LE12 5RD, UK; and ${ }^{4}$ Faculty of Agriculture, University of Reading, \\ Whiteknights, Reading RG6 6AJ, UK
}

Freemartins are sterile $\mathrm{XX} / \mathrm{XY}$ chimaeras that occur as a result of placental fusion between male and female fetuses during early pregnancy. Freemartins occur predominantly in cattle, although the prevalence of ovine freemartinism is increasing. In this study, the reproductive endocrinology of ovine freemartins was compared with that of normal sheep. Freemartins had significantly $(P<0.001)$ higher basal concentrations of $\mathrm{LH}$ and FSH than did normal ewes or rams, although the response of $\mathrm{LH}$ to $\mathrm{GnRH}(10 \mu \mathrm{g})$ was similar in freemartins, ewes and rams. Resting concentrations of oestradiol were similar in freemartins and ewes and were increased in both after eCG administration. Testosterone concentrations were higher in freemartins than in ewes, but were unresponsive to GnRH or eCG. Administration of $62.5 \mathrm{mg}$ progesterone or

\section{Introduction}

Freemartins are $\mathrm{XX/XY}$ chimaeras that develop as a consequence of fusion of the chorioallantoic circulation in pregnancies consisting of at least one male and one female fetus (McEntee, 1990). Freemartinism is a common condition of cattle that affects $>90 \%$ of the female calves from mixed-sex pregnancies (Marcum, 1974) and, consequently, is of economic significance to the cattle breeding industry. Traditionally, ovine freemartinism has been regarded as a rare abnormality (Dain, 1971; Long, 1980; Matejka et al., 1987), despite the high incidence of multiple pregnancies in sheep. However, over the past 10-15 years, the prevalence of ovine freemartinism has increased significantly (Bindon et al., 1987; Cribiu et al., 1990; Gill and Davies, 1991), largely as a consequence of changes in patterns of sheep breeding. Over this period, new breeds of sheep, which have much larger litters than traditional breeds, have been developed as a result of the discovery of high fecundity genes (see King, 1996). The risk of freemartinism is greatly increased in the progeny of ewes that carry litters of four or

Email: T.J.Parkinson@massey.ac.nz
$25 \mu \mathrm{g}$ oestradiol twice a day for 3 days suppressed LH concentrations to baseline values in freemartins, ewes and rams. In ewes, $500 \mu \mathrm{g}$ oestradiol administered twice a day caused preovulatory surges in $\mathrm{LH}$ concentrations, but suppressed LH in freemartins to baseline values. Thus, LH secretion can potentially be regulated in freemartins by gonadal steroids. FSH concentrations in freemartins were not suppressed by doses of inhibin that were effective in ewes and rams. Therefore, freemartins behave in part like castrated animals, as they have high basal concentrations of LH and FSH, which can be stimulated by GnRH and suppressed by gonadal steroids. Conversely, inhibin does not suppress FSH concentrations in freemartins, and freemartins have circulating concentrations of steroids intermediate between those of castrated and normal animals.

more lambs (Bindon et al., 1987), so freemartinism occurs largely in such breeds.

The anatomical features of freemartinism are well recognized. The gonads of bovine freemartins are usually vestigial and there is either a marked hypoplasia or a complete aplasia of the paramesonephric ducts. Masculinization of the gonads occurs occasionally in more extreme cases and, in most of such cases, there is also development of the mesonephric ducts. Affected animals have rudimentary epididymides, vasa deferentia, pampiniform plexes and vesicular glands (Roberts, 1986; McEntee, 1990). Similar morphological abnormalities are present in ovine freemartins, although it is usual for both the gonads and the mesonephric ducts to be much more masculinized than in cattle (Wilkes et al., 1978; Cribiu and Matejka, 1985; Smith, 1996). Thus, a typical ovine freemartin has gonads that resemble testes; only a small proportion have vestigial, undifferentiated gonads (Bruere and McNab, 1968; Chaffaux et al., 1987; Smith, 1996). The parenchyma of such vestigial gonads is composed of structures that resemble degenerating sex cords, whereas the parenchyma of masculinized gonads closely resembles testicular tissue, with clearly defined tubular structures and interstitial 
regions (McEntee, 1990). It is common for masculinized gonads of ovine freemartins to descend from the abdominal cavity to an inguinal position. Freemartin heifers and freemartin ewes are invariably anoestrous, but many ovine freemartins display clearly masculine patterns of behaviour (Bruere and McNab, 1968; Chaffaux et al., 1987; Smith et al., 2000).

Several hypotheses have been developed to explain the means by which placental fusion leads to the development of freemartinism. It is thought that anti-Müllerian factor, secreted from the gonad of the male fetus, crosses into the circulation of the female fetus, where it prevents development of the ovaries and paramesonephric ducts (Burgoyne, 1988; Behringer, 1995). Further masculinization of the genital tract of the female fetus is caused by androgens from both the male fetus and, due to alterations in its patterns of steroidogenesis (Shore and Shemesh, 1981), from the gonad of the female (freemartin) fetus (Jost et al., 1963; Dominguez et al., 1990). Exposure of the fetal female hypothalamus to androgens also androgenizes its activity, such that the subsequent behaviour of the hypothalamo-pituitary axis is more likely to resemble that of a male than that of a normal female (Connolly and Resko, 1994; Herbosa et al., 1996).

Relatively little is known of the reproductive endocrinology of freemartin animals. Some endocrine studies of bovine freemartins have been undertaken but, other than attempts to devise endocrine tests for the clinical diagnosis of the condition (Dobson and Davies, 1989; Spedding and Dobson, 1989), few detailed studies have been made of ovine freemartins. The aim of the present study was to investigate the activity of the pituitary-gonadal axis of ovine freemartins, particularly so that the effects of masculinization on the reproductive endocrine system could be better understood. A series of four experiments was carried out to investigate the activity and feedback mechanisms of the reproductive endocrine axis in freemartin sheep after treatment with $\mathrm{GnRH}$, eCG, progesterone, oestradiol or semi-purified bovine follicular fluid (inhibin).

\section{Materials and Methods}

\section{Animals}

Freemartins were obtained from a number of flocks of prolific ewes in south-west England. Freemartinism was diagnosed initially by the absence of oestrous cycles and the presence of a short $(<5 \mathrm{~cm}$ in length) vagina. The diagnosis was confirmed by demonstrating the presence of $X X / X Y$ chimaerism in lymphocytes (Long et al., 1996) that were cultured from sterile jugular venous blood samples. The freemartins were 1.0-2.5 years old. Control animals were either (i) 18-month-old intact ewes, (ii) intact rams of mixed ages or (iii) 18-month-old males that had been castrated shortly after birth (castrated males).

All of the experiments were carried out during the breeding season of the control ewes, starting in October and completed during February. Throughout the experiments the sheep were housed in pens containing 3-6 animals, under conditions of ambient photoperiod and temperature. Access to hay and water was available ad libitum and the sheep were also given $0.25 \mathrm{~kg}$ of molassed beet pulp per day. When freemartins were used in more than one experiment, there was an interval of at least 2 weeks between experiments. An interval of 4 weeks was allowed between Expts 3 and 4.

The sheep were killed at the completion of the experiments. Their reproductive tracts were recovered and those of the freemartins were described in detail. The freemartins were classified retrospectively into male-type and undifferentiated-type, on the basis of the macroscopic and histological appearance of their gonads.

\section{Experiment 1: treatment with different doses of $\mathrm{GnRH}$}

The short-term responses of freemartins $(n=11)$ and control ewes $(n=15)$ to a low dose of GnRH (Expt 1a) and the longer-term response of freemartins and control ewes and rams ( $n=8$ per group) to a higher dose of GnRH (Expt $1 \mathrm{~b})$ were investigated. Oestrus was synchronized in control ewes by administration of two doses of $250 \mu \mathrm{g}$ cloprostenol (Estrumate; Malinckrodt Veterinary Ltd, Harefield) 10 days apart, with the experiments taking place on day 9 or 10 of the cycle (12 days after the second cloprostenol injection). In Expt 1a, blood samples were collected by jugular venepuncture at $-30,0,20$ and 60 min relative to the time of administration of an i.v. bolus of 250 ng GnRH (Fertagyl; Intervet UK Ltd, Cambridge; Khalid et al., 1987) in $2 \mathrm{ml}$ $0.9 \%(\mathrm{w} / \mathrm{v})$ saline. All venepuncture samples were collected using evacuated glass tubes containing lithium heparin anticoagulant (Vacutainer; Becton-Dickinson, Meylan Cedex). In Expt 1b, jugular venous cannulae were positioned $24 \mathrm{~h}$ before the start of blood sampling. Blood samples $(5 \mathrm{ml}$; sodium heparin anticoagulant) were collected at $-2,-1,0$, $1,2,3,4,5$ and 6 h relative to the time of i.v. administration of $10 \mu \mathrm{g} \mathrm{GnRH} \mathrm{(Fertagyl;} \mathrm{Intervet} \mathrm{UK} \mathrm{Ltd;} \mathrm{Rhind} \mathrm{et} \mathrm{al.,}$ $1989)$ in $2 \mathrm{ml} \mathrm{0.9 \%}(\mathrm{w} / \mathrm{v})$ saline.

Plasma was separated by centrifugation at $1000 \mathrm{~g}$ for 15 min immediately after the collection of blood samples and was stored at $-20^{\circ} \mathrm{C}$ until assayed. Concentrations of $\mathrm{LH}$ were measured in all samples. Concentrations of testosterone were measured in all samples from Expt 1b, but in Expt $1 \mathrm{a}$ they were measured in the first and last samples from each animal only.

\section{Experiment 2: treatment with eCG}

The effects of eCG on gonadal steroids and gonadotrophins were studied in two experiments, using the animals studied previously in Expt 1. In Expt 2a, oestrus was synchronized in control ewes $(n=15)$ by the same cloprostenol-based regimen used in Expt 1. Blood sampling started on day 12 after the second cloprostenol injection. In Expt 2b, progestagen-releasing intravaginal sponges (medroxyprogesterone acetate: Veramix; Upjohn UK Ltd, Crawley) were positioned in the control ewes $(n=8)$ and 
blood sampling commenced 4 days after sponge placement. Other animals (Expt 2a: freemartins $(n=11)$; Expt 2b: freemartins $(n=8)$ and rams $(n=8))$ were untreated before the start of blood sampling.

In both experiments, blood samples were collected by jugular venepuncture at $0,24,30,48,54$ and $72 \mathrm{~h}$ relative to the i.m. injection of 1000 iu eCG (PMSG; Intervet UK Ltd) in $1 \mathrm{ml}$ sterile water. Concentrations of $\mathrm{LH}$ and $\mathrm{FSH}$ were measured in all samples. Concentrations of oestradiol were measured in samples collected in Expt 2a, and testosterone concentrations were measured in samples collected in Expt 2b.

\section{Experiment 3: steroid feedback on gonadotrophins}

Freemartins, ewes and long-term castrated males $(n=5$ per group) were treated with different doses of progesterone and oestradiol to examine their feedback effects upon gonadotrophins. The experiment was conducted over 6 weeks, with animals receiving progesterone, oestradiol or vehicle each week.

Ewes were given $250 \mu \mathrm{g}$ cloprostenol (Estrumate; Malinckrodt Veterinary Ltd) 2 days before the start of the experiment to ensure lysis of any active endogenous luteal tissue. During week 1, each animal received i.m. injections of $12.5 \mathrm{mg}$ (low dose) progesterone (Intervet UK Ltd) in $2 \mathrm{ml}$ arachis oil, every $12 \mathrm{~h}$ for $72 \mathrm{~h}$. Jugular venous cannulae were positioned during day 2 of treatment. On day 3 , blood samples (2.5 ml; sodium heparin anticoagulant) were collected every $10 \mathrm{~min}$ for $6 \mathrm{~h}$. After 2 days, the control ewes were given $250 \mu \mathrm{g}$ cloprostenol (Estrumate). All animals were then rested for 2 days.

This protocol was repeated each week, changing the steroid treatments as follows: week 2: vehicle (2 $\mathrm{ml}$ arachis oil per $12 \mathrm{~h}$ ); week 3: $25 \mu \mathrm{g}$ oestradiol (Intervet UK Ltd) in $2 \mathrm{ml}$ arachis oil per $12 \mathrm{~h}$ (low dose); week 4: vehicle (2 ml arachis oil per $12 \mathrm{~h}$ ); week 5: $500 \mu \mathrm{g}$ oestradiol (high dose) in $2 \mathrm{ml}$ arachis oil per $12 \mathrm{~h}$; and week 6: $62.5 \mathrm{mg}$ progesterone (high dose) in $2 \mathrm{ml}$ arachis oil per $12 \mathrm{~h}$.

Concentrations of $\mathrm{LH}$ were measured in every sample. Concentrations of $\mathrm{FSH}$, testosterone, progesterone and oestradiol were measured once a day in plasma that was pooled over $2 \mathrm{~h}$ of the sampling period.

\section{Experiment 4: inhibin feedback on FSH}

Semi-purified bovine follicular fluid was used as a source of inhibin to study the feedback regulation of gonadotrophins further. Oestrus was induced in control ewes $(n=5)$ by a single injection of $250 \mu$ g cloprostenol (Estrumate) 7 days before the start of blood sampling. Freemartins $(n=5)$ and rams $(n=5)$ were untreated before the start of the experiment. The freemartins were the same animals that had been used in Expt 3. Blood samples (2 ml) were collected every $2 \mathrm{~h}$ for $8 \mathrm{~h}$ per day for 5 days through jugular venous cannulae that had been positioned $24 \mathrm{~h}$ before the start of sampling. Day 1 of the experiment was a control period, during which baseline concentrations of
FSH were established. On days 2, 3 and 4, bovine follicular fluid $(5 \mathrm{ml}$ ) was administered twice per day ( $8 \mathrm{~h}$ apart) through the jugular cannulae. No follicular fluid was given on day 5 of the experiment. Concentrations of FSH were measured in all samples. LH concentrations were measured in the first, third and final samples of each day. Testosterone and inhibin concentrations were measured in one sample from each day.

Bovine follicular fluid was prepared from ovaries collected from a local abattoir. The ovaries were transported to the laboratory on ice, where fluid was aspirated from follicles $>6 \mathrm{~mm}$ in diameter. Small molecules were removed by incubation with $0.5 \%(\mathrm{v} / \mathrm{w})$ activated charcoal (Sigma Chemical Co. Ltd, Poole) plus $0.1 \%(\mathrm{w} / \mathrm{v})$ dextran (BDH Merck Ltd, Poole) at room temperature for $3 \mathrm{~h}$, followed by centrifugation at $5000 \mathrm{~g}$ for $30 \mathrm{~min}$ and filtration of the supernatant to remove the charcoal. The resulting preparation was stored at $-20^{\circ} \mathrm{C}$ until required. Inhibin content was validated by radioimmunoassay at sequential dilutions. Significant increases in circulating concentrations of inhibin were observed after administration of the follicular fluid to sheep.

\section{Hormone assays}

Concentrations of $\mathrm{LH}, \mathrm{FSH}$, testosterone and oestradiol were measured using established radioimmunoassay techniques (McNeilly et al., 1986; Parkinson and Follett, 1994; Mann et al., 1995). Concentrations of progesterone were measured by the ELISA method described by Groves et al. (1990). Concentrations of inhibin were determined using the method of Beard et al. (1990), modified by using the antiserum prepared by Robertson et al. (1989) and validated for use in sheep by Miller et al. (1997). Details of reagents and assay validation criteria for each of these assays are given (Table 1 ).

\section{Analysis of data}

All endocrine data were normalized by logarithmic $\left(\log _{\mathrm{e}}\right)$ transformation and were subjected to analysis of variance with respect to gender (freemartin, ewe, ram or castrated male) and time, in a repeated measures model in which individual animals were nested within gender. Least significant differences were calculated where statistically significant effects were noted (Snedecor and Cochran, 1967). In a number of the experiments no significant differences between undifferentiated-type and male-type freemartins were present in the initial analysis. Data for such experiments were reanalysed with undifferentiatedtype and male-type as a single group.

In Expt 3, an episode of LH secretion was considered to have occurred when: (i) there was an increase in concentration from the preceding nadir of at least $1 \mathrm{ng} \mathrm{ml}^{-1}$; (ii) concentrations were increased for at least three consecutive samples between successive nadirs; and (iii) the rate of decay was within the limits of the known half-life of LH (Geschwind and Dewey, 1968; Lamming and McLeod, 
Table 1. Details of hormone assay reagents and validation criteria

\begin{tabular}{|c|c|c|c|c|c|c|c|}
\hline Assay & $\begin{array}{l}\text { Sample } \\
\text { volume }\end{array}$ & Standard & Label & Antiserum & Sensitivity & $\begin{array}{l}\text { Inter-assay } \\
\text { CV (\%) }\end{array}$ & $\begin{array}{c}\text { Intra-assay } \\
\text { CV }(\%)\end{array}$ \\
\hline $\mathrm{LH}$ & $50 \mu \mathrm{l}$ & $\mathrm{NIH} 0 \mathrm{OL}-\mathrm{S} 23^{\mathrm{a}}$ & $125[$ [I] LER-1374Aa & McNeilly R29b & $0.05 \mathrm{ng} \mathrm{ml}^{-1}$ & 12.0 & 4.8 \\
\hline FSH & $50 \mu \mathrm{l}$ & LER 1976-A2a & ${ }^{125}$ [I] LER 1976-A2 & NIDDK anti-oFSHa & $0.05 \mathrm{ng} \mathrm{ml}^{-1}$ & 12.5 & 5.2 \\
\hline Inhibin & $50 \mu \mathrm{l}$ & $\begin{array}{l}M_{\mathrm{r}} 32000 \\
\text { bovine inhibin }\end{array}$ & $\begin{array}{l}{ }^{125}[I] M_{r} 32000 \\
\text { bovine inhibin }{ }^{c}\end{array}$ & $\begin{array}{l}\text { Monash antiserum } \\
1989^{d}\end{array}$ & $0.5 \mathrm{ng} \mathrm{ml}^{-1}$ & sa & 11.8 \\
\hline Oestradiol & $250 \mu \mathrm{l}$ & Oestradiole $^{\mathrm{e}}$ & $125[\mathrm{I}]$ Oestradiol ${ }^{f}$ & E2 MAIA & $0.6 \mathrm{pg} \mathrm{ml}^{-1}$ & sa & 12.5 \\
\hline Progesterone & $10 \mu \mathrm{l}$ & Progesterone $\mathrm{e}^{\mathrm{e}}$ & $\begin{array}{l}\text { Progesterone-11 } \alpha \text { - } \\
\text { glucuronide } \\
\text { alkaline } \\
\text { phosphataseg }\end{array}$ & $\begin{array}{l}\text { Anti-progesterone } \\
\text { monoclonalg }\end{array}$ & $0.1 \mathrm{ng} \mathrm{ml}^{-1}$ & 15.9 & 5.9 \\
\hline Testosterone & $5 \mu \mathrm{l}$ & Testosterone $\mathrm{e}^{\mathrm{e}}$ & $125\left[\right.$ II]Testosterone ${ }^{\mathrm{h}}$ & $\begin{array}{l}\text { Antiserum } \\
8680-6004^{\mathrm{h}}\end{array}$ & $0.02 \mathrm{ng} \mathrm{ml}^{-1}$ & 10.5 & 9.7 \\
\hline
\end{tabular}

CV: coefficient of variation; sa: single assay.

aDonated by the National Hormone and Pituitary Programme, Baltimore, MD.

${ }^{b}$ Antiserum to ovine LH was donated by A. S. MCNeilly, MRC Centre for Reproductive Biology, Edinburgh.

'See Beard et al. (1990) for details.

dSee Robertson et al. (1989) for details.

eSigma Chemical Co, Poole.

fSerono Diagnostics, Woking.

gRidgeway Science, Cirencester.

hBiogenesis Ltd, Boldon.

1988). Episode frequency and amplitude were calculated from this information. These data were not subjected to statistical analysis.

\section{Results}

\section{Classification of freemartin types}

The freemartins were classified retrospectively into 'male' and 'undifferentiated' types, on the basis of the anatomical and histological appearance of their gonads at post-mortem examination. Male-type freemartins had large gonads that resembled testes macroscopically. The gonads were either in an inguinal position or were situated in the ventral abdomen near the internal inguinal ring. These animals also had rudimentary epididymides, vasa deferentia, pampiniform plexes or vesicular glands. Histologically, the parenchyma of their gonads contained tubular structures and interstitial tissue, thereby resembling the testes of prepubertal animals. The gonads of undifferentiated-type freemartins were small (approximately $0.5 \mathrm{~cm}$ in length), situated within the broad ligament and had the gonadal whorls characteristic of undifferentiated gonadal parenchyma. Structures derived from the paramesonephric ducts were vestigial in both male-type and undifferentiated-type sheep.

\section{Summary of results}

A generalized summary of the results of each experiment is shown (Table 2). Data from undifferentiated- and maletype freemartins are presented separately for the sake of completeness, even when data from the two types of freemartin were combined subsequently for statistical analysis. Detailed results of each experiment are given below.

\section{Experiment 1}

Of the 11 freemartins used in Expt 1a, eight were classified retrospectively as male-type and three as undifferentiated-type. Six of the freemartins used in Expt $1 \mathrm{~b}$ were male-type and two were undifferentiated-type.

In Expt 1a, mean LH concentrations were significantly $(P<0.001)$ higher in male-type $\left(7.47 \pm 0.44 \mathrm{ng} \mathrm{ml}^{-1}\right)$ and undifferentiated-type $\left(7.83 \pm 0.28 \mathrm{ng} \mathrm{ml}^{-1}\right)$ freemartins than in ewes $\left(0.77 \pm 0.06 \mathrm{ng} \mathrm{ml}^{-1}\right)$. Small but nonsignificant increases in $\mathrm{LH}$ concentrations occurred in all groups of animals after GnRH administration. Mean testosterone concentrations were significantly $(P<0.01)$ higher in male-type $\left(1.08 \pm 0.01 \mathrm{ng} \mathrm{ml}^{-1}\right)$ than undifferentiatedtype $\left(0.06 \pm 0.01 \mathrm{ng} \mathrm{ml}^{-1}\right)$ freemartins and ewes $(0.07 \pm$ $0.01 \mathrm{ng} \mathrm{ml}^{-1}$ ), but no significant changes in testosterone concentrations after GnRH treatment were observed in any group (data not shown, but see Table 2 ).

In Expt 1b, there was a significant $(P<0.001)$ interaction between gender and time (with respect to administration of GnRH) in determining $\mathrm{LH}$ and testosterone concentrations (Fig. 1a). Pre-treatment $\mathrm{LH}$ concentrations in freemartins were significantly $(P<0.001)$ higher than in ewes or rams. Concentrations were significantly increased after $\mathrm{GnRH}$ treatment, with maximum concentrations occurring $1 \mathrm{~h}$ after treatment. Maximum values in rams were significantly $(P<0.05)$ higher than in ewes, with freemartins (undifferentiated-type and male-type) occupying an intermediate position.

The pre-treatment testosterone concentrations of 
Table 2. Summary of results

\begin{tabular}{|c|c|c|c|c|c|c|c|}
\hline \multirow[b]{2}{*}{ Hormone } & \multirow[b]{2}{*}{ Treatment } & \multirow[b]{2}{*}{ Parameter } & \multicolumn{5}{|c|}{ Group of animals } \\
\hline & & & $\begin{array}{c}\text { MF } \\
\text { freemartin }\end{array}$ & $\begin{array}{c}\text { UF } \\
\text { freemartin }\end{array}$ & Ewe & Ram & $\begin{array}{c}\text { Castrated } \\
\text { male }\end{array}$ \\
\hline \multicolumn{2}{|l|}{ Expt 1a } & $n$ & 8 & 3 & 15 & - & - \\
\hline \multirow[t]{2}{*}{ LH } & Pre-treatment: 250 ng GnRH & Basal concentration $\left(\mathrm{ng} \mathrm{ml}^{-1}\right)$ & 6.4 & 6.3 & 0.59 & - & - \\
\hline & & Peak concentration $\left(\mathrm{ng} \mathrm{ml}^{-1}\right)$ & 8.5 & 10.0 & 1.09 & - & - \\
\hline \multirow[t]{2}{*}{ Testosterone } & e Pre-treatment : $250 \mathrm{ng}$ GnRH & Basal concentration $\left(\mathrm{ng} \mathrm{m}^{-1}\right)$ & 0.61 & 0.18 & 0.06 & - & - \\
\hline & & Peak concentration $\left(\mathrm{ng} \mathrm{ml}^{-1}\right)$ & 0.75 & 0.06 & 0.08 & - & - \\
\hline \multicolumn{2}{|l|}{ Expt $1 b$} & $n$ & $6^{\mathrm{a}}$ & $2^{\mathrm{a}}$ & 8 & 8 & - \\
\hline \multirow[t]{3}{*}{ LH } & Pre-treatment: $10 \mu \mathrm{g} \mathrm{GnRH}$ & Basal concentration $\left(\mathrm{ng} \mathrm{ml}^{-1}\right)$ & 4.4 & 5.2 & 0.42 & 0.36 & - \\
\hline & & Peak concentration $\left(\mathrm{ng} \mathrm{ml}^{-1}\right)$ & $10.6 \boldsymbol{\uparrow}^{\mathrm{b}}$ & $15.9 \boldsymbol{\uparrow}^{b}$ & $8.2 \uparrow$ & $12.2 \uparrow$ & - \\
\hline & & Time to peak concentration (h) & 2 & 1 & 1 & 1 & - \\
\hline \multirow[t]{3}{*}{ Testosterone } & e Pre-treatment: $10 \mu \mathrm{g} \mathrm{GnRH}$ & Basal concentration $\left(\mathrm{ng} \mathrm{ml}^{-1}\right)$ & 0.79 & 0.29 & 0.14 & 2.4 & - \\
\hline & & Peak concentration $\left(\mathrm{ng} \mathrm{ml}^{-1}\right)$ & 1.33 & 0.60 & 0.27 & $7.9 \uparrow$ & - \\
\hline & & Time to peak concentration (h) & - & - & - & 2 & - \\
\hline \multicolumn{2}{|l|}{ Expt 2a } & $n$ & 8 & 3 & 15 & - & - \\
\hline \multirow[t]{3}{*}{ Oestradiol } & Pre-treatment: 1000 iu eCG & Basal concentration $\left(\mathrm{pg} \mathrm{ml}^{-1}\right)$ & 2.7 & 3.5 & 5.0 & - & - \\
\hline & & Peak concentration $\left(\mathrm{ng} \mathrm{ml}^{-1}\right)$ & $20.7 \uparrow$ & $10.8 \uparrow$ & $27.8 \uparrow$ & - & - \\
\hline & & Time to peak concentration (h) & 30 & 30 & 30 & - & - \\
\hline \multirow[t]{3}{*}{$\mathrm{LH}$} & Pre-treatment: 1000 iu eCG & Basal concentration $\left(\mathrm{ng} \mathrm{ml}^{-1}\right)$ & 6.8 & 7.5 & 0.8 & - & - \\
\hline & & Peak concentration $\left(\mathrm{ng} \mathrm{ml}^{-1}\right.$ ) & 10.0 & 11.4 & $2.1 \uparrow$ & - & - \\
\hline & & Time to peak concentration $(\mathrm{h})$ & (54) & $(48)$ & 24 & - & - \\
\hline \multirow{3}{*}{ FSH } & Pre-treatment: 1000 iu eCG & Basal concentration $\left(\mathrm{ng} \mathrm{ml}^{-1}\right)$ & 18.4 & 24.2 & 5.1 & - & - \\
\hline & & Minimum concentration $\left(\mathrm{ng} \mathrm{ml}^{-1}\right)$ & 16.0 & 19.6 & $1.25 \downarrow$ & - & - \\
\hline & & Time to nadir $(\mathrm{h})$ & $(24)$ & $(24)$ & 72 & - & - \\
\hline \multicolumn{2}{|l|}{ Expt $2 b$} & $n$ & $6^{\mathrm{a}}$ & $2^{\mathrm{a}}$ & 8 & 8 & - \\
\hline \multirow{3}{*}{ Testosterone } & e Pre-treatment: 1000 iu eCG & Basal concentration $\left(\mathrm{ng} \mathrm{ml}^{-1}\right)$ & 1.01 & 0.42 & 0.09 & 1.32 & - \\
\hline & & Peak concentration $\left(\mathrm{ng} \mathrm{ml}^{-1}\right)$ & 1.10 & 0.85 & 0.26 & $22.4 \uparrow$ & - \\
\hline & & Time to peak concentration (h) & - & - & - & 54 & - \\
\hline \multirow[t]{3}{*}{$\mathrm{LH}$} & Pre-treatment: 1000 iu eCG & Basal concentration $\left(\mathrm{ng} \mathrm{ml}^{-1}\right)$ & 3.8 & 3.0 & 0.28 & 0.44 & - \\
\hline & & Peak concentration $\left(\mathrm{ng} \mathrm{ml}^{-1}\right)$ & 4.6 & 5.1 & $1.04 \uparrow$ & $1.01 \uparrow$ & - \\
\hline & & Time to peak concentration $(\mathrm{h})$ & $(48)$ & $(54)$ & 24 & 24 & - \\
\hline \multirow[t]{3}{*}{ FSH } & Pre-treatment: 1000 iu eCG & Basal concentration $\left(\mathrm{ng} \mathrm{ml}^{-1}\right)$ & 10.0 & 8.5 & 3.6 & 2.2 & - \\
\hline & & Minimum concentration $\left(\mathrm{ng} \mathrm{ml}^{-1}\right)$ & 8.5 & 8.5 & $0.83 \downarrow$ & $1.00 \downarrow$ & - \\
\hline & & Time to nadir $(\mathrm{h})$ & $(24)$ & $(24)$ & 48 & 54 & - \\
\hline \multicolumn{2}{|l|}{ Expt 3} & $n$ & $5^{\mathrm{a}}$ & $5^{\mathrm{a}}$ & 5 & - & 5 \\
\hline $\mathrm{LH}$ & Untreated & Mean concentration $\left(\mathrm{ng} \mathrm{ml}^{-1}\right)$ & 5.8 & 6.5 & 0.56 & - & 4.9 \\
\hline & Progesterone (12.5 mg twice a day) & Mean concentration $\left(\mathrm{ng} \mathrm{ml}^{-1}\right)$ & 3.9 & 4.8 & 0.39 & - & 4.7 \\
\hline & Progesterone (62.5 mg twice a day) & Mean concentration $\left(\mathrm{ng} \mathrm{ml}^{-1}\right)$ & $0.61 \downarrow^{b}$ & $2.1 \downarrow^{b}$ & $0.17 \downarrow$ & - & $0.79 \downarrow$ \\
\hline & Oestradiol (25 $\mu$ g twice a day) & Mean concentration $\left(\mathrm{ng} \mathrm{ml}^{-1}\right)$ & 3.4 & 3.5 & 0.43 & - & $1.72 \downarrow$ \\
\hline & Oestradiol ( $500 \mu \mathrm{g}$ twice a day) & Mean concentration $\left(\mathrm{ng} \mathrm{ml}^{-1}\right)$ & 2.8 & 2.2 & $3.6 \uparrow$ & - & $1.23 \downarrow$ \\
\hline FSH & Untreated & Mean concentration $\left(\mathrm{ng} \mathrm{ml}^{-1}\right)$ & 11.0 & 11.0 & 3.6 & - & 10.8 \\
\hline & Progesterone (12.5 mg twice a day) & Mean concentration $\left(\mathrm{ng} \mathrm{ml}^{-1}\right)$ & 11.0 & 11.0 & 5.5 & _- & 11.0 \\
\hline & Progesterone (62.5 mg twice a day) & Mean concentration $\left(\mathrm{ng} \mathrm{m}^{-1}\right)$ & 10.3 & 9.6 & $2.2 \downarrow$ & - & 9.2 \\
\hline & Oestradiol (25 $\mu$ g twice a day) & Mean concentration $\left(\mathrm{ng} \mathrm{ml}^{-1}\right)$ & 11.0 & 11.0 & $1.80 \downarrow$ & - & 10.2 \\
\hline & Oestradiol (500 $\mu$ g twice a day) & Mean concentration $\left(\mathrm{ng} \mathrm{ml}^{-1}\right)$ & 10.4 & 10.4 & $2.4 \downarrow$ & - & 9.7 \\
\hline Expt 4 & & $n$ & $5^{\mathrm{a}}$ & $5^{\mathrm{a}}$ & 5 & 5 & - \\
\hline LH & Pre-treatment & Mean concentration $\left(\mathrm{ng} \mathrm{ml}^{-1}\right)$ & 8.5 & 6.2 & 0.84 & 0.97 & - \\
\hline & bFF ( $5 \mathrm{ml}$ twice a day) for 3 days & Mean concentration $\left(\mathrm{ng} \mathrm{ml}^{-1}\right)$ & 6.9 & 6.6 & 0.95 & 0.65 & - \\
\hline & Post-treatment & Mean concentration $\left(\mathrm{ng} \mathrm{ml}^{-1}\right)$ & 6.4 & 7.6 & $2.1 \uparrow$ & 0.81 & - \\
\hline FSH & Pre-treatment & Mean concentration $\left(\mathrm{ng} \mathrm{ml}^{-1}\right)$ & 9.4 & 7.8 & 3.9 & 2.2 & - \\
\hline & bFF ( $5 \mathrm{ml}$ twice a day) for 3 days & Mean concentration $\left(\mathrm{ng} \mathrm{ml}^{-1}\right)$ & 9.0 & 6.9 & $2.7 \downarrow$ & $1.03 \downarrow$ & - \\
\hline & Post-treatment & Mean concentration $\left(\mathrm{ng} \mathrm{m}^{-1}\right)$ & 9.2 & 6.5 & $6.5 \uparrow$ & $1.15 \downarrow$ & - \\
\hline
\end{tabular}

MF: male-type freemartin, UF: undifferentiated-type freemartin; bFF: bovine follicular fluid.

$\downarrow \uparrow$ : Significant $(P<0.05)$ increase or decrease in concentration above or below basal values.

a Data from undifferentiated- and male-type freemartins were combined for statistical analysis.

bMeans of the combined data were significantly different from basal values $(P<0.05)$.

The time to peak concentration is relative to the time of administration of GnRH or eCG. Where a time value is given in parentheses, the difference between peak and basal values was not significant. 
(a)

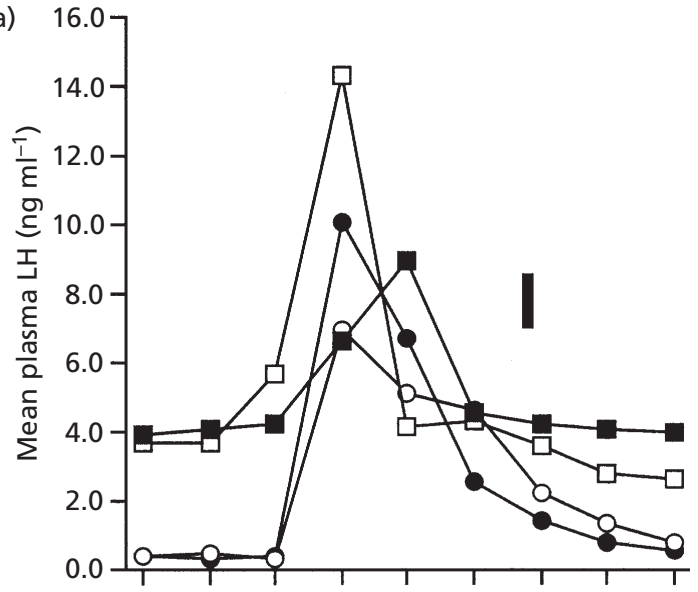

(b)

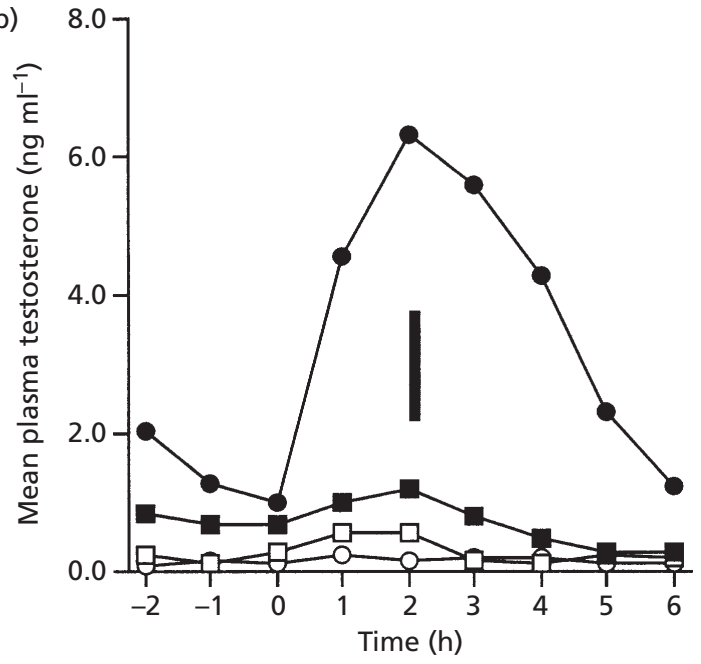

Fig. 1. Expt 1b. Mean (geometric) concentrations of (a) LH and (b) testosterone in ewes $(\bigcirc ; n=8)$, rams $(-n=8)$, male-type freemartins $(\square ; n=6)$ and undifferentiated-type freemartins $(\square$; $n=2)$ after administrations of $10 \mu \mathrm{g} \mathrm{GnRH}$. The vertical bars represent the anti-log of the residual SED from the analysis of variance of the $\log _{\mathrm{e}}$-transformed data.

freemartins were significantly higher than in ewes but lower than in rams (both $P<0.05$ ). Testosterone concentrations were significantly $(P<0.05)$ increased in rams after administration of $\mathrm{GnRH}$, whereas no such increase occurred in ewes. In both male-type and undifferentiatedtype freemartins, there was a small but non-significant increase in testosterone concentrations after administration of $\mathrm{GnRH}$.

\section{Experiment 2}

Eight male-type and three undifferentiated-type freemartins were used in Expt 2a. Data from undifferentiatedtype and male-type freemartins are presented separately for this experiment. In Expt 2b, six of the freemartins were male-type and two were undifferentiated-type. There were no significant differences between the endocrine data from undifferentiated-type and male-type freemartins in this experiment, so these data were combined and re-analysed.

Steroids. In Expt 2a, the pre-treatment concentrations of oestradiol (Fig. 2a) in male-type $\left(2.7 \pm 0.8 \mathrm{pg} \mathrm{ml}^{-1}\right)$ and undifferentiated-type $\left(3.5 \pm 1.0 \mathrm{pg} \mathrm{m}^{-1}\right)$ freemartins did not differ significantly from those of control ewes $(5.0 \pm 1.9 \mathrm{pg}$ $\left.\mathrm{ml}^{-1}\right)$. In control ewes, oestradiol concentrations increased significantly $(P<0.01)$ by $30 \mathrm{~h}$ after eCG administration $\left(27.8 \pm 4.1 \mathrm{pg} \mathrm{ml}^{-1}\right)$ and remained above pre-treatment values for the remainder of the experiment. A shorter-term increase in oestradiol concentrations was observed in male-type freemartins: by $30 \mathrm{~h}$ after eCG administration their oestradiol concentrations $\left(17.0 \pm 6.3 \mathrm{pg} \mathrm{ml}^{-1}\right)$ were significantly $(P<0.01)$ higher than during the control period but, although values continued to increase until $48 \mathrm{~h}$ after administration of eCG, they returned to pre-treatment values thereafter. In undifferentiated-type freemartins, a transient increase in oestradiol concentrations (maximum value: $10.8 \pm 3.4 \mathrm{pg} \mathrm{ml}^{-1}$ ) occurred $48 \mathrm{~h}$ after administration of eCG. However, concentrations had decreased to pre-treatment values by $54 \mathrm{~h}$.

In Expt 2b, testosterone concentrations (Fig. 2b) during the pre-treatment period were highest in rams $(1.32 \pm 0.35$ $\left.\mathrm{ng} \mathrm{ml}^{-1}\right)$ and lowest in ewes $\left(0.09 \pm 0.01 \mathrm{ng} \mathrm{ml}^{-1} ; P<0.01\right)$. Values in freemartins $\left(0.86 \pm 0.36 \mathrm{ng} \mathrm{ml}^{-1}\right)$ were significantly different $(P<0.05)$ from those in either rams or ewes. No significant changes in testosterone concentrations occurred in ewes, undifferentiated-type or male-type freemartins after eCG treatment. However, in rams, concentrations increased significantly $(P<0.05)$ from $24 \mathrm{~h}$ after treatment until the end of the experiment $(24 \mathrm{~h}$ : $7.6 \pm 1.3 \mathrm{ng} \mathrm{ml}^{-1} ; 72 \mathrm{~h}: 21.7 \pm 4.4 \mathrm{ng} \mathrm{ml}^{-1}$ ).

Gonadotrophins. The patterns of $\mathrm{LH}$ and FSH concentrations were similar in both Expt 2a and Expt 2b (Fig. 3a), with significant $(P<0.001)$ differences in concentrations among groups of sheep relative to the time of administration of eCG. In both experiments, pre-treatment LH concentrations in male-type and undifferentiated-type freemartins were higher $(P<0.01)$ than in ewes. Small but nonsignificant increases in $\mathrm{LH}$ concentrations occurred in freemartins after eCG administration, whereas in ewes (Expts $2 \mathrm{a}$ and $2 \mathrm{~b}$ ) and rams (Expt 2b), concentrations of $\mathrm{LH}$ were significantly $(P<0.01, P<0.05$ and $P<0.05$, respectively) higher $24 \mathrm{~h}$ after administration of eCG than in the pre-treatment period. Such increases in LH concentrations were sustained for the remainder of the experiment.

Similarly, in both Expts $2 \mathrm{a}$ and $2 \mathrm{~b}$, pre-treatment FSH concentrations in male-type and undifferentiated-type freemartins were higher $(P<0.05)$ than in ewes (Fig. 3b). There were no significant effects of eCG administration on the FSH concentrations of freemartins in either experiment. However, a significant $(P<0.01)$ decrease in FSH concentrations was observed in all the ewes and rams from the time of eCG administration for the remainder of the experiments. 

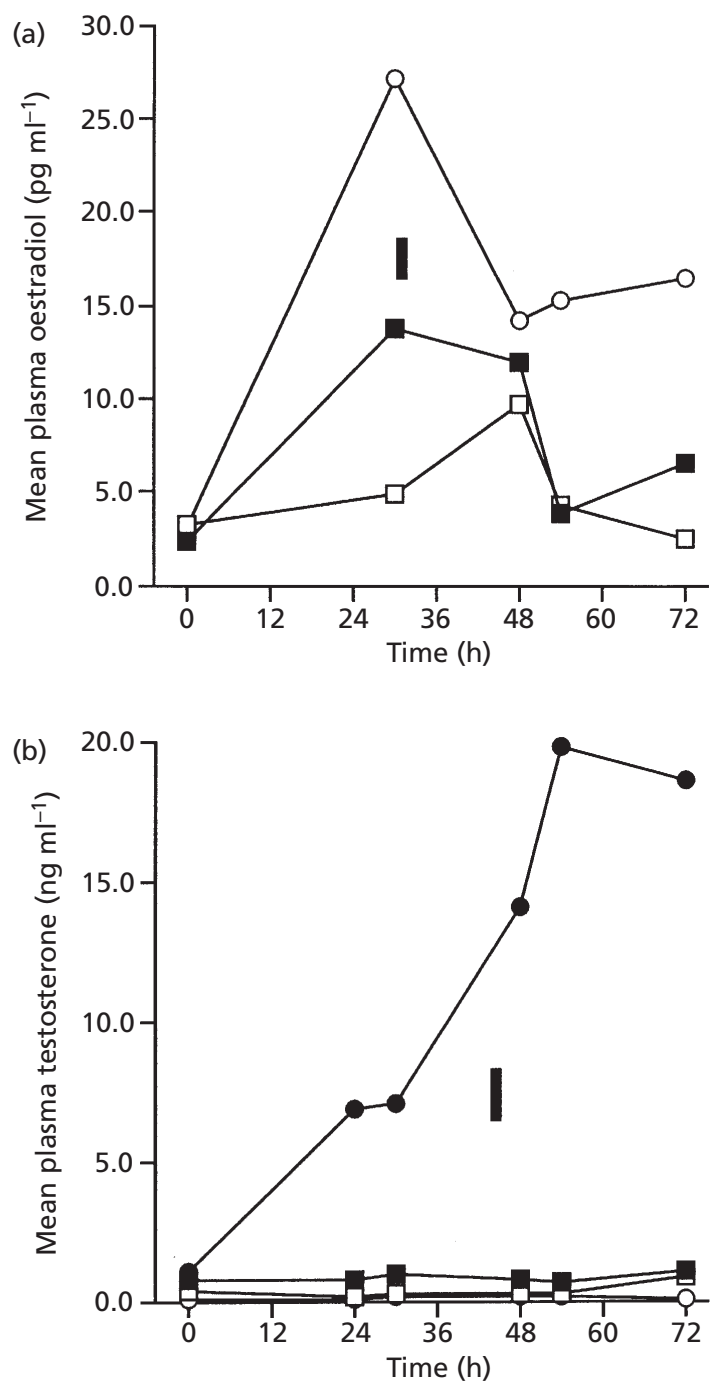

Fig. 2. Effects of administration of 1000 iu eCG on (a) concentrations of oestradiol (Expt 2a) in ewes $(O ; n=15)$, male-type freemartins $(\mathbf{\square} ; n=8)$ and undifferentiated-type freemartins $(\square ; n=3)$ and (b) concentrations of testosterone (Expt 4) in ewes $(\bigcirc ; n=8)$, rams $(\mathbf{O} ; n=8)$, male-type freemartins $(\mathbf{\square} ; n=6)$ and undifferentiated-type freemartins $(\square ; n=2)$. Points represent mean (geometric) concentrations. The vertical bars represent the anti-log of the residual SED from the analysis of variance of the $\log _{\mathrm{e}}{ }^{-}$ transformed data.

\section{Experiment 3}

Three of the freemartins used in this experiment were classified retrospectively as male-type and two as undifferentiated-type. The steroid administration regimens increased circulating concentrations of progesterone and oestradiol into the physiological (low dose) or supraphysiological (high dose) ranges (Table 3). There were no significant differences in concentrations of steroids among groups of sheep within a treatment period or between the two control periods.
Table 3. Concentrations of progesterone and oestradiol in steroidtreated sheep

\begin{tabular}{lcc}
\hline Treatment & $\begin{array}{c}\text { Oestradiol } \\
\text { concentration* } \\
\left(\mathrm{pg} \mathrm{ml}^{-1}\right)\end{array}$ & $\begin{array}{c}\text { Progesterone } \\
\text { concentration* } \\
\left(\mathrm{ng} \mathrm{ml}^{-1}\right)\end{array}$ \\
\hline Control & $0.90 \pm 0.08^{\mathrm{a}}$ & $0.50 \pm 0.10^{\mathrm{a}}$ \\
Low dose progesterone & $0.82 \pm 0.06^{\mathrm{a}}$ & $6.60 \pm 0.89^{\mathrm{b}}$ \\
High dose progesterone & $0.38 \pm 0.15^{\mathrm{a}}$ & $>20.0^{\mathrm{c}}$ \\
Low dose oestradiol & $6.54 \pm 2.01^{\mathrm{b}}$ & $1.04 \pm 0.41^{\mathrm{a}}$ \\
High dose oestradiol & $52.33 \pm 3.63^{\mathrm{c}}$ & $0.38 \pm 0.13^{\mathrm{a}}$ \\
\hline
\end{tabular}

Values are mean \pm SEM.

See text for details of steroid treatment regimens.

*Combined mean for all sheep (freemartins, ewes and castrated males) receiving each steroid treatment.

Control: combined mean for both control periods.

Within treatments, differences between groups were not significantly different. abc Values within columns with different superscripts are significantly different $(P<0.05)$.

There were significant differences in $\mathrm{LH}$ and $\mathrm{FSH}$ concentrations (both $P<0.001$ ) among freemartins, ewes and castrated males during the different steroid treatments. Data from the two control periods were combined, as there were no significant differences in any parameter of $\mathrm{LH}$ or $\mathrm{FSH}$ secretion between the two periods. Likewise, there were no differences between undifferentiated-type and male-type freemartins during any treatments, so these data were also combined. During the control periods, LH concentrations (Table 2) in castrated males and freemartins were significantly $(P<0.01)$ higher than in ewes. The low dose of progesterone did not affect $\mathrm{LH}$ concentrations in any of the groups of animals (Table 2 and Fig. 4a), but the high dose of progesterone suppressed LH below control values in all groups $(P<0.05)$. The low dose of oestradiol suppressed LH concentrations of castrated males, but not of ewes or freemartins, to below control values $(P<0.05)$. Preovulatory LH surges (as determined by LH concentrations $>7 \mathrm{ng} \mathrm{ml}^{-1}$ in sequential samples throughout the period of blood sampling) were detected in three ewes after administration of the high dose of oestradiol, but this treatment suppressed LH concentrations in freemartins and castrated males below those of the control periods $(P<0.01)$. LH pulse frequency (Fig. 4 b) was very low in all groups during treatment with the high dose of progesterone. In freemartins, the LH pulse frequency was lower during all of the periods of steroid treatment than during the control periods, but a substantial decrease in frequency during administration of the high doses of both steroids was observed in castrated males only. In ewes, no LH pulses were evident except during administration of the high dose of oestradiol.

Circulating concentrations of FSH were high in freemartins and castrated males throughout the experiment and were unaffected by any steroid treatment. Concentrations in ewes 

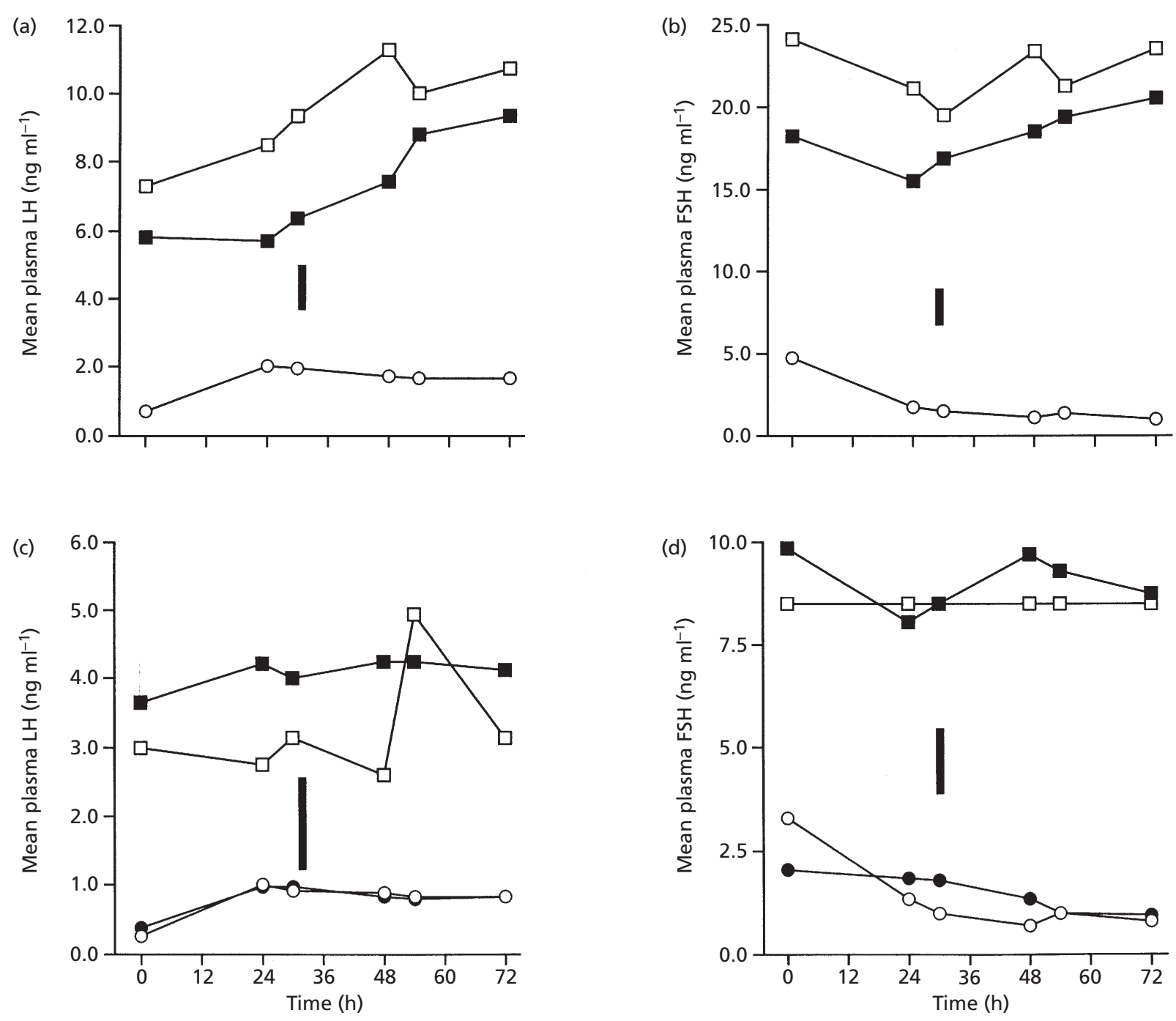

Fig. 3. Effects of administration of 1000 iu eCG on $(a, c)$ LH and (b,d) FSH concentrations in ewes (O), male-type freemartins (ם) and undifferentiated-type freemartins ( $\square$ ) in (a,b) Expt 2a and (c,d) Expt 2b. Points represent geometric mean values. The vertical bars represent the anti-log of the residual SED from the analysis of variance of the $\log _{\mathrm{e}}$-transformed data.

were significantly $(P<0.01)$ lower than in either freemartins or castrated males, and concentrations in ewes were also lower during administration of high doses of progesterone or either dose of oestradiol (all $P<0.05$ ) than at other times (Table 2).

\section{Experiment 4}

Of the freemartins used in this experiment, three were male-type and two were undifferentiated-type. Initially, the data were analysed separately for the two groups of freemartins but the data were subsequently combined, as there were no significant differences in any of the endocrine parameters between the two types of freemartin.

Circulating concentrations of inhibin (Fig. 5a) were significantly $(P<0.01)$ higher in rams than in ewes or freemartins throughout the experiment. In both ewes and freemartins, inhibin concentrations increased significantly $(P<0.01)$ during the period of bovine follicular fluid administration. An increase in inhibin concentrations also occurred in rams during bovine follicular fluid administration, but the difference from control values was not significant. After cessation of bovine follicular fluid administration, inhibin concentrations of ewes and freemartins decreased back to control values. Concentrations in rams also decreased after the cessation of bovine follicular fluid administration, decreasing to values that were significantly $(P<0.05)$ lower than during the control period.

There was a significant $(P<0.001)$ interaction between gender and time (with respect to the administration of bovine follicular fluid) in determining FSH concentrations 

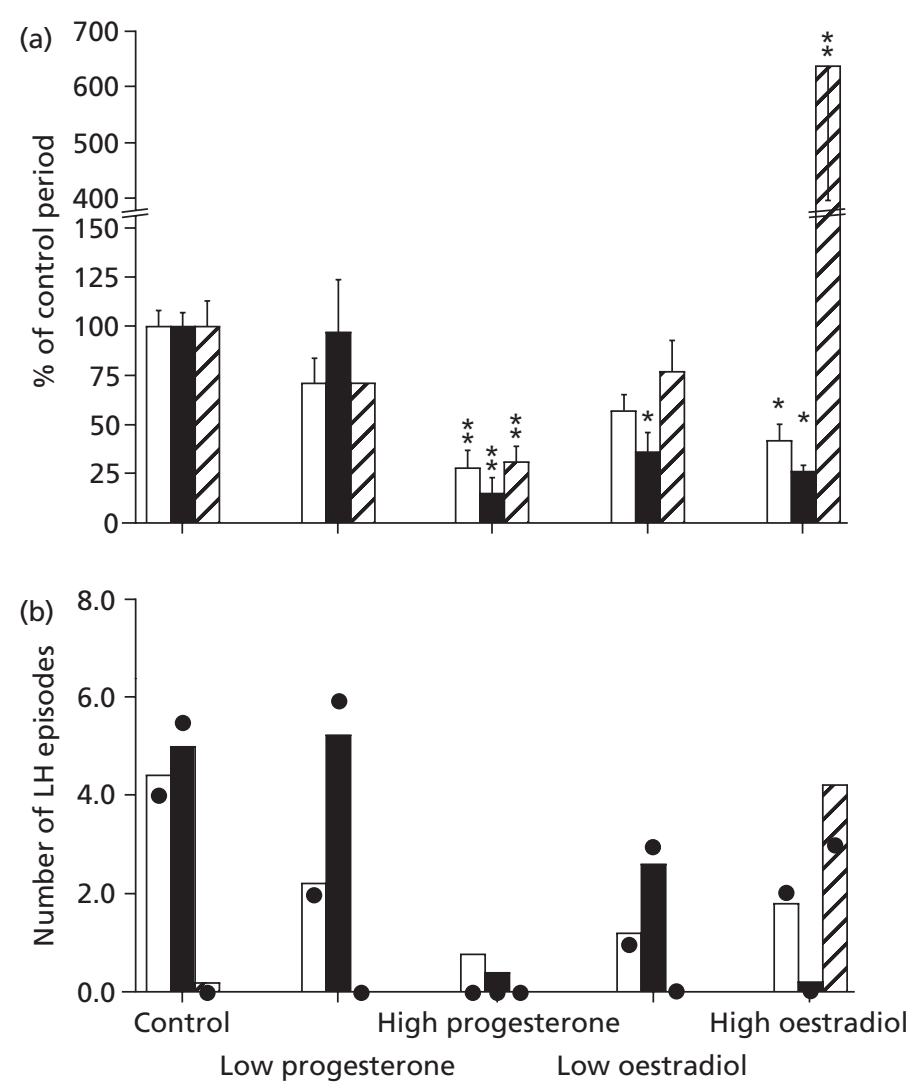

Fig. 4. Expt 3. Effects of steroid treatment on $\mathrm{LH}$ secretion in freemartins $(\square ; n=5)$, castrated males $(\mathbf{\square} ; n=5)$ and ewes (四; $n=5$ ). (a) Arithmetic mean \pm SEM concentrations of LH during the $6 \mathrm{~h}$ period of blood sampling, expressed as a percentage of the value during the control periods. Values differ from controls where indicated: ${ }^{*} P<0.05$ and ${ }^{*} P<0.01$. (b) Mean (bars) and median ( frequency of LH episodes during $6 \mathrm{~h}$ period of blood sampling. Data from male-type and undifferentiated-type freemartins are combined.

(Fig. 5b). Pre-treatment concentrations in freemartins (overall mean for undifferentiated-type and male-type: $\left.8.79 \pm 0.88 \mathrm{ng} \mathrm{ml}^{-1}\right)$ were significantly $(P<0.05)$ higher than in ewes $\left(3.87 \pm 0.06 \mathrm{ng} \mathrm{ml}^{-1}\right)$ or rams $(2.15 \pm 0.59 \mathrm{ng}$ $\mathrm{ml}^{-1}$ ). Throughout the period of bovine follicular fluid administration, FSH concentrations in ewes and rams were significantly lower than pre-treatment values. By day 3 of treatment, values had decreased to $2.68 \pm 0.61 \mathrm{ng} \mathrm{ml}^{-1}$ in ewes $(P<0.01)$ and $0.83 \pm 0.20 \mathrm{ng} \mathrm{ml}^{-1}$ in rams $(P<0.01)$. On the day after cessation of bovine follicular fluid treatment, $\mathrm{FSH}$ concentrations had increased slightly in rams (1.15 $\pm 0.34 \mathrm{ng} \mathrm{ml}^{-1}$; not significant) and significantly in ewes $\left(6.54 \pm 0.85 \mathrm{ng} \mathrm{ml}^{-1} ; P<0.01\right)$. In contrast, FSH concentrations in freemartins were maintained at very high values throughout the experiment (overall mean for the 5 days: $8.56 \pm 0.82 \mathrm{ng} \mathrm{ml}^{-1}$ ) and were unchanged by bovine follicular fluid administration. Likewise, LH concentrations (Table 2) in freemartins were unaffected by bovine follicular fluid administration, remaining at much higher values $(P<0.01)$ than in either ewes or rams. LH concentrations in rams were unaffected by bovine follicular fluid administration, whereas in ewes, a small but significant $(P<0.05)$ increase in concentrations occurred over the duration of investigation.

\section{Discussion}

A considerable degree of masculinization was observed in the ovine freemartins used in these experiments, as 17 of the 24 animals had large, testis-like gonads that were located in the vicinity of the inguinal canal. The other seven freemartins had small, undifferentiated gonads. Such a pattern of gonadal development is typical of the descriptions of ovine freemartinism in the literature (for example, Bruere and McNab, 1968) and is the reverse of the situation in cattle, in which most freemartins have vestigial gonads (Marcum, 1974; Khan and Foley, 1994). The freemartins with testis-like gonads (male-type) also had many other masculinized features, such as the presence of epididymides, vasa deferentia and vesicular glands. 

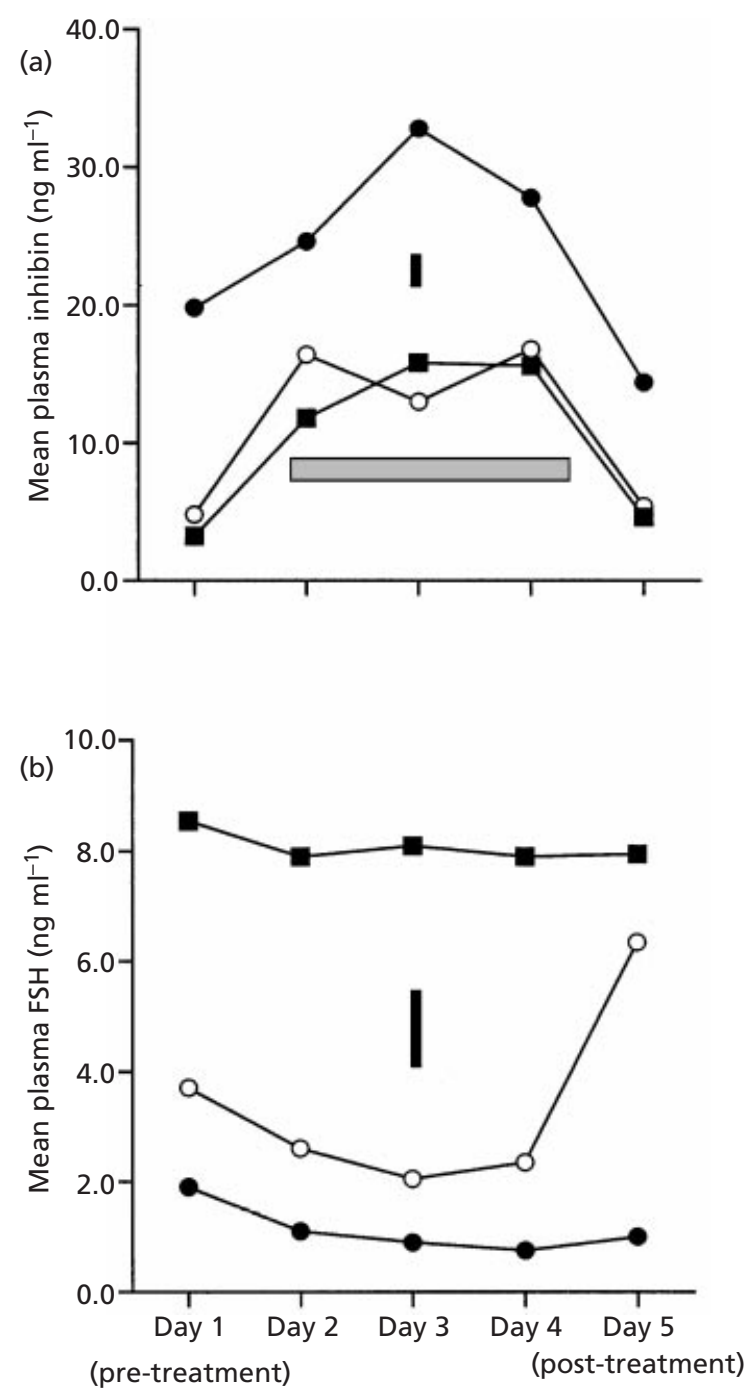

Fig. 5. Expt 4. Mean (geometric) concentrations of (a) FSH and (b) LH after administration of semi-purified inhibin (charcoal-stripped bovine follicular fluid) to ewes $(0 ; n=5)$, rams $(\bullet ; n=5)$ and freemartins $(\mathbf{\square} ; n=5)$. The period of bovine follicular fluid administration is shown by the horizontal stippled bar. Data from male-type and undifferentiated-type freemartins are combined. The vertical bars represent the anti-log of the residual SED from the analysis of variance of the $\log _{\mathrm{e}}$-transformed data.

Moreover, they had structures resembling pampiniform plexes and cremaster muscles associated with the gonad. A lesser degree of mesonephric duct development was present in freemartins with undifferentiated gonads (undifferentiated-type), although most had rudimentary vesicular glands. Structures derived from the paramesonephric ducts were absent or vestigial in both undifferentiated-type and male-type freemartins. Again, these patterns of development of the paramesonephric and mesonephric ducts are representative of previous descriptions of bovine and ovine freemartinism (Bruere and McNab, 1968; Marcum, 1974; McEntee, 1990).
Many studies of the embryological differentiation of the genital system have indicated that the development of the mesonephric duct is androgen-dependent (Jost et al., 1972; Wilson et al., 1983). Development of the urogenital sinus into the external male genitalia is dependent on dihydrotestosterone, whereas development of the upper parts of the mesonephric ducts into structures such as the epididymis is dependent on testosterone (Schultz and Wilson, 1973; Siiteri and Wilson, 1974; Wilson et al., 1980; Tsuji et al., 1991) and can be prevented by administration of antiandrogens (Steinbecker et al., 1970). In freemartins, transformation of the female gonad is thought to be initiated by anti-Müllerian factor from the male co-twin (Burgoyne, 1988), while much of the subsequent development of the masculinized phenotype of freemartins is driven by androgens from the male co-twin and from the freemartin gonad itself (Shore and Shemesh, 1981; Dominguez et al., 1990). Masculinization occurs largely during the embryonic and fetal periods, but probably persists into post-natal life, as Greene et al. (1979) found that testosterone treatment of bovine freemartins continued to cause clitoral development after birth.

The results of the present study demonstrate the presence of significant quantities of testosterone in the circulation of ovine freemartins, thereby confirming earlier reports from small numbers of animals (Saba et al., 1977; Braun et al., 1983; Bosu and Basrur, 1984; Kenny et al., 1992). These results, together with the presence of $3 \beta$-hydroxysteroid dehydrogenase within the interstitial-like tissue of the gonads (Smith, 1996), indicate that the gonad is the likely source of the steroid, whereas the much lower concentrations of testosterone in undifferentiated-type compared with maletype freemartins makes an extra-gonadal (for example, adrenal) source improbable. However, testosterone concentrations were almost completely unresponsive to either GnRH (Expt 1) or eCG (Expt 2b) administration, which might be considered as evidence against a gonadal source of steroid. It is possible that masculinized freemartin gonads are inherently unresponsive to gonadotrophins (for example, due to an absence of specific receptors) or their gonads may be already fully stimulated by the high circulating concentrations of GnRH present. Some support for this hypothesis can be found in the study of Schanbacher (1979), who reported that testosterone concentrations of cryptorchid bulls are unresponsive to $\mathrm{GnRH}$. However, the gonads of fetal bovine freemartins are responsive to $\mathrm{LH}$ for a longer period of gestation (> 120 days) than normal male fetal gonads (up to day 75 of gestation; Shore et al., 1984). It seems that freemartin gonads cease to be responsive to gonadotrophic stimulation at some point between the end of the first trimester of pregnancy and adulthood, a long time after masculinization begins.

The patterns of oestradiol concentrations, particularly their responsiveness to stimulation by eCG, are the most difficult of the present results to understand, for they indicate that the vestigial gonads of undifferentiated-type freemartins can produce oestrogen in a gonadotrophinresponsive manner. For male-type freemartins, such a 
response presents no problems, as the presence of seminiferous tubule-like structures within their gonads may permit the Sertoli-like cells of the tubules to undertake a substantial amount of oestrogen synthesis. The similar resting concentrations of oestradiol in undifferentiated-type freemartins and normal ewes, or the mechanism by which those concentrations might be affected by eCG, are more difficult to explain. Indeed, it was expected that ovine undifferentiated-type freemartins would have behaved much more like their bovine counterparts, which have low or undetectable circulating oestradiol concentrations and very slight gonadal oestrogenic activity only (Dominguez et al., 1990).

Nevertheless, the gonads of even undifferentiated-type freemartins contain $3 \beta$-hydroxysteroid dehydrogenase and alkaline phosphatase. These enzymes are not associated with the gonadal whorls, but are scattered throughout the interstitium, in cells that do not display the morphological characteristics of steroidogenic tissue (Smith et al., in press). Lun et al. (1998) showed that the mesonephros is capable of steroid synthesis independent of the fetal gonad. Moreover, mesonephric tissue does not have the morphological characteristics that are classically associated with steroidogenic activity. It is possible that the persistence of mesonephric remnants within the vestigial gonad of undifferentiated-type freemartins explains the presence of steroidogenic activity. The sequence of masculinization of bovine freemartin gonads described by Vigier et al. (1977) supports such a contention. Inhibition of ovarian development is complete by day 50 of gestation, and is followed by the earliest phase of masculinization, namely the development of the mesonephros (up to day 75). Development of seminiferous cords and interstitial tissue does not take place until between day 90 and day 100. If the gonad of the undifferentiated-type freemartin is considered to be an intermediate stage between degeneration of the ovary and the full gonadal masculinization of typical ovine freemartins, it is possible that mesonephric remnants are present within the gonads of undifferentiated-type freemartins. If so, and if such tissue were to persist into adulthood, the steroidogenic activity of the mesonephros reported by Lun et al. (1998) could account for the oestrogenic activity of undifferentiated-type freemartin gonads.

Several previous studies of freemartin ewes support the present findings that peripheral concentrations of $\mathrm{LH}$ and FSH are very much higher than in intact animals, with a pattern of pulsatility that resembles that of castrated males (Saba et al., 1977; Dobson and Davies, 1989; Spedding and Dobson, 1989). Wilkes et al. (1978) reported that peripheral $\mathrm{LH}$ concentrations of freemartins were higher than in ovariectomized ewes and, in the present study, LH concentrations in freemartins were higher than in castrated males. Given this high LH secretion in freemartins, the responses to $\mathrm{GnRH}$ stimulation were largely as expected; namely, that no increase in LH concentrations was observed in freemartins in response to a low dose of GnRH
(Expt 1a), whereas their response to a much higher dose of $\mathrm{GnRH}$ was only small (Expt 1b). Gonadotrophin responses of intact ewes to eCG administration were also largely as expected, with concentrations of $\mathrm{LH}$ increasing and those of FSH decreasing. Conversely, changes in gonadotrophin concentrations in male-type or undifferentiated-type freemartins in response to eCG were small, probably because of the lack of follicular tissue within their gonads.

Nevertheless, in Expt 3 it was clear that freemartins were as susceptible to the negative feedback effects of oestrogen and progesterone on $\mathrm{LH}$ as either intact ewes or castrated males. However, freemartins did not display a positive feedback response to oestradiol, such as occurred in normal ewes. This finding indicates that the LH surge mechanism may be ablated in freemartins, which is a common feature of masculinization of the female hypothalamus (Herbosa et al., 1996). No other investigations of positive feedback responses of ovine freemartins were found, although some studies have been undertaken in cattle that support the results of the present experiments. For example, Saba et al. (1976) reported that only one of 19 freemartins underwent an LH surge after administration of $500 \mu \mathrm{g}$ oestradiol, although a higher dose $(1.0 \mathrm{mg})$ was more effective (Cunningham et al., 1977). In the present study, ovine freemartins received either 50 or $1000 \mu$ g oestradiol per day, so it appears that they are, if anything, even less sensitive to its positive feedback effects than their bovine counterparts. This finding may be a further indication of the greater degree of masculinization in ovine compared with bovine freemartins.

However, the most remarkable result from the present study was the failure of inhibin to suppress FSH secretion in freemartins. Although the dose of inhibin that was used was effective at suppressing FSH concentrations in ewes and rams in the present and other studies (Cummings et al., 1983; Findlay and Clarke, 1987), it failed to suppress FSH concentrations in freemartins. This lack of responsiveness to high doses of inhibin provides strong evidence for a dysfunction of the feedback of inhibin on FSH in freemartins.

In conclusion, the endocrine effects of the masculinization that occurs during development of freemartins are widespread. Not only does morphological alteration of the gonad and genitalia take place, but the relationships between the gonadal endocrine products and their trophic regulators are also significantly affected. The main evidence for the alteration of the function of the freemartin hypothalamo-pituitary axis is derived from the failure to elicit a positive feedback response of LH to oestradiol (a response regulated via hypothalamic pathways) and from the abnormal responses of FSH to inhibin feedback. This perturbation of the hypothalamo-pituitary-gonadal axis of freemartin sheep cannot be explained simply by reference to the reproductive endocrinology of ewes or of intact or castrated males.

The authors are grateful to A. S. McNeilly for his gift of LH antiserum and to NIH for gifts of the standards and antisera for use 
in the other gonadotrophin radioimmunoassays. The authors are grateful to B. Rosevink for his invaluable technical support and $\mathrm{K}$. Lapwood for his help in preparation of the manuscript. Finally, the authors would like to gratefully acknowledge the support of the many farmers who identified and supplied us with freemartin ewes.

\section{References}

Beard AJ, Castillo RJ, McLeod BJ, Glencross RG and Knight PG (1990) Comparison of the effects of crude and highly purified inhibin $\left(M_{r}\right.$ 32000 ) on plasma concentrations of $\mathrm{FSH}$ and $\mathrm{LH}$ in chronically ovariectomised prepubertal heifers Journal of Endocrinology 125 21-30

Behringer RR (1995) The Mullerian inhibitor and mammalian sexual development Philosophical Transactions of the Royal Society of London Series B 350 285-289

Bindon BM, Piper LM, Curtis YM and Nethery RD (1987) Freemartins in Booroola Merino populations Proceedings of the Australian Society of Reproductive Biology 17108 (Abstract)

Bosu WTK and Basrur PK (1984) Morphological and hormonal features of an ovine and a caprine intersex Canadian Journal of Comparative Medicine 48 402-409

Braun U, Forster M and Schams D (1983) Freemartinism in sheep morphological, hormonal and cytogenic investigations Tierarztliche Praxis 11 293-302

Bruere AN and McNab J (1968) A cytogenetical investigation of 6 intersex sheep shown to be freemartins Research in Veterinary Science 9 170-180

Burgoyne PS (1988) Role of mammalian $Y$ chromosome in sex determination Philosophical Transactions of the Royal Society of London Series B 322 63-72

Chaffaux St, Matejka M, Cribiu EP, Crespeau F, Eychenne F and Ricordeau G (1987) Cytological, anatomical and histological study of two Romanov freemartins Recueil de Médicine Véterinaire 163 15-21

Connolly PB and Resko JA (1994) Prenatal testosterone differentiates brain regions controlling gonadotropin release in guinea pigs Biology of Reproduction 51 125-130

Cribiu EP and Matejka M (1985) Caryotype normal et anomalies chromosomiques du mouton domestique (Ovis aries L.). Récueil de Médicine Véterinaire 161 61-68

Cribiu EP, Durand V and Chaffaux St (1990) Frequency of freemartinism in Booroola Arles Merino ewe lambs Récueil de Médicine Véterinaire 16 919-922

Cummings LJ, O'Shea T, Bindon BM, Lee VWK and Findlay JK (1983) Ovarian inhibin content and sensitivity to inhibin in Booroola and control strain Merino ewes Journal of Reproduction and Fertility 67 $1-7$

Cunningham NF, Saba N and Boarer CD (1977) The acute effects of oestradiol-17b and synthetic LH-RH on plasma LH levels in freemartin heifers Journal of Reproduction and Fertility $\mathbf{5 1} 29-33$

Dain A (1971) The incidence of freemartinism in sheep Journal of Reproduction and Fertility 24 91-97

Dobson H and Davies DAR (1989) Development of an endocrine challenge test to investigate subfertility in ewes British Veterinary Journal $\mathbf{1 4 5}$ $523-530$

Dominguez MM, Liptrap RM, Croy BA and Basrur PK (1990) Hormonal correlates of ovarian alterations in bovine freemartin fetuses Animal Reproduction Science 22 181-201

Findlay JK and Clarke IJ (1987) Regulation of the secretion of FSH in domestic ruminants Journal of Reproduction and Fertility Supplement 34 27-37

Geschwind II and Dewey R (1968) Dynamics of luteinising hormone (LH) secretion in the cycling ewe: a radio-immunoassay study Proceedings of the Society for Experimental Biology and Medicine 129 451-455

Gill JJB and Davies DAR (1991) XX/XY chromosomal chimaerism in infertile sheep of the Cambridge breed Genetique, Selection et Evolution 23 (Supplement 1) 126-130

Greene WA, Mogil LG, Lein DH, McCauley AD and Foote RH (1979) Growth and reproductive development in freemartins hormonally treated from 1 to 79 weeks of age Cornell Veterinarian 69 248-261

Groves DJ, Sauer MJ, Rayment P, Foulkes JA and Morris BA (1990) The preparation of an ovine monoclonal antibody to progesterone Journal of Endocrinology 126 217-222

Herbosa CG, Dahl GE, Evans NP, Pelt J, Wood RI and Foster DL (1996) Sexual differentiation of the surge mode of gonadotropin secretion: prenatal androgens abolish the gonadotropin-releasing hormone surge in the sheep Journal of Neuroendocrinology 8 627-633

Jost A, Chodkiewicz M and Mauléon P (1963) Intersexualitié du foetus de veau produite par des androgèns. Comparaison entre I'hormone foetal responsible du freemartinisme et l'hormone testiculaire adulte Comptes Rendus Hebdomadaire des Séances de l'Academie des Sciences 256 274-276

Jost A, Vigier B and Perpin J (1972) Freemartins in cattle: the first steps of sexual organogenesis Journal of Reproduction and Fertility 29 349-379

Kenny DE, Cambre RC, Frahm MW and Bunch TD (1992) Freemartinism in a captive herd of Rocky Mountain Bighorn sheep (Ovis canadensis). Journal of Wildlife Diseases 28 494-498

Khalid M, Haresign W and Hunter MG (1987) Pulsatile GnRH administration stimulates the number of pituitary $\mathrm{GnRH}$ receptors in seasonally anoestrous ewes Journal of Reproduction and Fertility 79 223-230

Khan MZ and Foley GL (1994) Retrospective studies on the measurements, karyotyping and pathology of reproductive organs of bovine freemartins Journal of Comparative Pathology $11025-36$

King JWB (1996) Historical background and recognition of prolific sheep. In Prolific sheep pp 3-7 Ed. MH Fahmy. CAB International, Wallingford

Kursonov KM (1960) Pseudoplacentary vascular anastomosis in embryonic parabiosis and the appearance of freemartinism in sheep. Translation of Proceedings of the Academy of Sciences (USSR). Biological Sciences Section 711-714

Lamming GE and McLeod BJ (1988) Continuous infusion of GnRH reduces the $\mathrm{LH}$ response to an intravenous $\mathrm{GnRH}$ injection but does not inhibit endogenous $\mathrm{LH}$ secretion in cows Journal of Reproduction and Fertility 82 237-246

Long SE (1980) Some pathological conditions of the reproductive tract of the ewe Veterinary Record 106 175-176

Long SE, Smith KC and Parkinson TJ (1996) Chromosome complement and external phenotype of 25 infertile sheep Archivos de Zootecnia 45 185-189

Lun S, Smith P, Lundy T, O'Connell A, Hudson N and McNatty KP (1998) Steroid contents of and steroidogenesis in vitro by the developing gonad and mesonephros around sexual differentiation in fetal sheep Journal of Reproduction and Fertility 114 131-139

McEntee K (1990) Reproductive Pathology of Domestic Mammals Academic Press Inc, New York

McNeilly AS, Jonassen JA and Fraser HM (1986) Suppression of follicular development after chronic LHRH immunoneutralization in the ewe Journal of Reproduction and Fertility 76 481-490

Mann GE, Lamming GE and Fray MD (1995) Plasma oestradiol during early pregnancy in the cow and the effects of treatment with buserelin Animal Reproduction Science 49 561-566

Marcum JB (1974) The freemartin syndrome Animal Breeding Abstracts 42 227-242

Matejka M, Cribiu EP, Ricordeau G and Chaffeaux St (1987) Frequency of freemartinism in Romanov ewes Recueil de Medicine Veterinaire $\mathbf{1 6 3}$ 635-638

Miller S, Wongprasartsuk S, Young IR, Wlodek ME, McFarlane JR, de Kretser DM and Jenkin G (1997) Source of inhibin in ovine fetal plasma and amniotic fluid during late gestation: half-life of fetal inhibin Biology of Reproduction 57 347-353

Parkinson TJ and Follett BK (1994) Effect of thyroidectomy upon seasonality in the ram Journal of Reproduction and Fertility 101 51-58

Rhind SM, Martin GB, McMillen S, Tsonis CG and McNeilly AS (1989) Effect of level of food intake of ewes on the secretion of $\mathrm{LH}$ and $\mathrm{FSH}$ and on the pituitary response to gonadotropin-releasing hormone in ovariectomized ewes Journal of Endocrinology 121 325-330

Roberts SJ (1986) Veterinary Obstetrics and Genital Diseases (Theriogenology). Self-published, Ithaca, NY

Robertson DM, Giacometti M, Foulds LM, Lahnstein J, Goss NH, Hearn MTW and de Kretser DM (1989) Isolation of inhibin alpha-subunit 
precursor proteins from bovine follicular fluid Endocrinology 2141-2149

Saba N, Symons AM, Cunningham NF and Baorer CD (1976) The acute effect of oestrogen injection on plasma LH in freemartin heifers Journal of Reproduction and Fertility 48 317-321

Saba N, Cunningham NF and Boarer CD (1977) Plasma gonadotrophin and androgen concentrations in a freemartin ewe and its male sibling Journal of Reproduction and Fertility 51 113-117

Schanbacher BD (1979) Testosterone secretion in cryptorchid and intact bulls injected with gonadotropin-releasing hormone and luteinizing hormone Endocrinology 104 360-364

Schultz FM and Wilson JD (1973) Virilization of the Wolffian duct in the rat fetus Endocrinology 94 979-986

Shore L and Shemesh M (1981) Altered steroidogenesis by the fetal bovine freemartin ovary Journal of Reproduction and Fertility 63 309-314

Shore LS, Shemesh M and Mileguir F (1984) Foetal testicular steroidogenesis and responsiveness to $\mathrm{LH}$ in freemartins and their male co-twins International Journal of Andrology 7 87-93

Siiteri PK and Wilson JD (1974) Testosterone formation and metabolism during male sexual differentiation in the human embryo Journal of Clinical Endocrinology and Metabolism 38 113-125

Smith KC (1996) Reproductive Abnormalities in Ewes PhD thesis, University of Bristol

Smith KC, Parkinson TJ, Long SE and Barr FJ (2000) Anatomical and behavioural studies on freemartin ewes Veterinary Record 146 574-578

Smith KC, Long SE, Pearson GR, Sylvester L and Parkinson TJ Morphological and histological studies of the gonad and pituitary of the freemartin ewe Journal of Anatomy (in press)
Snedecor GW and Cochran WG (1967) Statistical Methods pp 223-224. lowa State University Press, lowa

Spedding RN and Dobson H (1989) Diagnosis of freemartinism in sheep Veterinary Record 123 18-19

Steinbecker H, Neumann F and Elger W (1970) Effect of an anti-androgen on the differentiation of the internal genital organs in dogs Journal of Reproduction and Fertility 23 223-227

Tsuji M, Shima H and Cunha GR (1991) In vitro androgen-induced growth and morphogenesis of the Wolfian duct within the urogenital ridge Endocrinology 128 1805-1811

Vigier B, Prepin J, Perchellet JP and Jost A (1977) Développment de l'effet freemartin chez le foetus de veau Annales de Médecine Véterinaire 121 $521-536$

Wilkes PR, Munro IB and Wijeratne WVS (1978) Studies on a sheep freemartin Veterinary Record 102 140-142

Wilson JD, Griffin JE and George FW (1980) Sexual differentiation: early hormone synthesis and action Biology of Reproduction 22 9-17

Wilson JD, Griffin JE, George FW and Leshin M (1983) The endocrine control of male phenotypic development Australian Journal of Biological Science 36 101-128

Resubmitted 14 December 2000

First decision 26 January 2001.

Final version received 16 May 2001.

Accepted 22 May 2001 